\title{
Logging Activity Adversely Impacts Primate Diversity and Density in the Kwabre Rainforest of Ghana
}

\author{
Emmanuel Danquah and Elvis Hackman Tetteh \\ Faculty of Renewable Natural Resources, College of Agriculture and Natural Resources, \\ Kwame Nkrumah University of Science and Technology, Kumasi, Ghana \\ Correspondence should be addressed to Emmanuel Danquah; emmanueldanquah@gmail.com
}

Received 24 March 2016; Revised 22 June 2016; Accepted 3 August 2016

Academic Editor: Ram Chander Sihag

Copyright (C) 2016 E. Danquah and E. H. Tetteh. This is an open access article distributed under the Creative Commons Attribution License, which permits unrestricted use, distribution, and reproduction in any medium, provided the original work is properly cited.

Knowledge on the impacts of logging activity on inhabitant primate species in Kwabre Rainforest, Ghana, is vital for the development of a comprehensive conservation and management plan. With this background, primate density and diversity were recorded along line transects in logged and unlogged areas (strata) to assess the impact of logging activity on these parameters. Six distinct primate species were confirmed including Roloway monkey (Cercopithecus roloway, listed as endangered in the IUCN List of Threatened Species), white-naped mangabey (Cercocebus lunulatus, vulnerable), and Geoffroy's black-and-white colobus (Colobus vellerosus, vulnerable). There was a significant difference (Mann-Whitney $U$ test: $U=36.0, p<0.01$ ) in primate encounter rates between the logged and unlogged strata with higher species diversity in unlogged stratum $(H=2.91)$ compared to the logged stratum $(H=$ 1.44). Regression analysis indicated a significant effect $\left(r^{2}=0.945, p<0.01\right)$ of logging on primate encounter rates. Our results suggest that logging activity can alter composition of primate communities. One option to forestall further forest degradation and its adverse effects on primates would be to grant the Kwabre Rainforest protected area status under Ghanaian law and manage it under an integrated conservation plan that includes neighbouring Ankasa Conservation Area in Ghana and Tanoé Forest in Cote d'Ivoire.

\section{Introduction}

The ability of many wildlife species to thrive in densely human populated areas depends largely on their level of tolerance for anthropogenic disturbances like deforestation and habitat fragmentation $[1,2]$. Primates are believed to be suitable biological indicators for assessing the effects of logging on wildlife habitats due to their strong connection with forest cover and vegetative complexity [3-5]. Apart from their responses to changes in vegetation structure which makes them good indicators, primates were selected over other species because their habitat requirements are better known and can be sampled with relatively simple methods like transects $[6,7]$.

In Ghana, the Kwabre Rainforest is a unique communityowned forest and it is reported to host several primate species of international conservation importance, including the Roloway monkey (Cercopithecus roloway), white-naped mangabey (Cercocebus lunulatus), and Geoffroy's black-andwhite colobus (Colobus vellerosus) $[8,9]$. These species are listed on the International Union for the Conservation of Nature's (IUCN) Red List of Threatened Species [10] and Appendix I of the Convention on International Trade in Endangered Species (CITES) [11, 12]. Unfortunately, the Kwabre Rainforest is exposed to an increasing risk of deforestation from illegal logging and farming activity. These activities, when unchecked, may adversely affect several species, particularly canopy dwelling primates. Existing studies of the impact of anthropogenic forest disturbance on primate populations have provided valuable insights into (i) effects of selective logging on primate density [13-18]; (ii) the role of habitat disturbances in diet selection and primate abundance [14, 19]; and (iii) behavioural and physiological responses of primates to habitat alteration $[20,21]$. In Ghana, no one has yet undertaken a quantitative assessment of the impacts of logging on primate abundance. This information is however vital to understand the sensitivities and habitat requirements of the species in order to develop an informed management plan.

The aim of this study was to examine the impact of logging activity on primate species in the Kwabre Rainforest 
in western Ghana. To meet this aim, censuses were conducted to (1) compare primate density and species composition between the logged and unlogged strata and (2) evaluate the effect of logging intensity on primate encounter rates. The null hypothesis predicts no significant difference in primate density and species composition between logged and unlogged areas. Conclusions drawn will contribute to managing primate conservation projects in this region and help to dictate future logging programmes in other rainforests. This study provides three important advantages over the earlier studies. One, it focuses on different groups of primate species, rather than just one species [22-24]. Two, it incorporates in its design a control area (an unlogged stratum) that was completely without any logging activity. This factor allowed a fairly objective assessment of the relative effects of logging activity on different primate species. Lastly, the study has both local and regional relevance, because the study area is a potentially key corridor between two designated national parks in Ghana and neighbouring Cote d'Ivoire, and this region of southwestern Ghana could be one of the most important areas for wildlife protection in West Africa.

\section{Materials and Methods}

2.1. Study Area. The Kwabre Rainforest, Ghana $\left(50 \mathrm{~km}^{2}\right.$; lat. $5^{\circ} 06^{\prime}-5^{\circ} 16^{\prime} \mathrm{N}$; long. $2^{\circ} 40^{\prime}-2^{\circ} 47^{\prime} \mathrm{W}$; Figure 1 ), is a communityowned swamp forest in the Western Region of Ghana and forms part of the Upper Guinean Forest Block. It is located close to the Ghana-Cote d'Ivoire international border, opposite to the Tanoé Forest. The area forms part of a network of forest reserves in southwestern Ghana which constitute Ghana's portion of the proposed transboundary elephant migration corridor between Ghana and Ivory Coast [25]. In addition, the Kwabre Rainforest makes up a crucial corridor for wildlife between the Ankasa Conservation Area in Ghana and the Tanoé community-managed forest in Cote d'Ivoire [9] (Figure 2). The area also forms part of the range of several flagship endangered primates, including the crowned mangabey, Roloway monkey, and Miss Waldron's red colobus, now considered extinct by primatologists $[9,26]$.

Selective logging of timber species by chainsaw operators and bushmeat hunting perpetrated by people coming from outside the local communities is destroying the original pristine habitat surrounding the Kwabre Rainforest area. Most of the logged areas are easily accessible from the main Takoradi-Elubo highway (Figure 1). The area is also exposed to an increasing risk of deforestation from farming for cash crops including rubber, palm oil, and cocoa, logging and mining activity, expanding fringe communities, and human encroachment on forest resources. The recent discovery of crude oil off the coast of Western Region with its attendant high local immigration as a result of the influx of job seekers has increased the human population density in the area.

2.2. Data Collection. The study area was classified into logged and unlogged strata (Figure 1) based on an initial reconnaissance to map out the presence or absence of logging activity. Primate surveys were conducted in the two strata using line transects. A total of six $500 \mathrm{~m}$ line transects $(3 \mathrm{~km})$ were established in each stratum. Transects were monitored consecutively over a survey period of two weeks in February 2014. The survey period comprised alternating each field day with a nonfield day in order to stagger disturbance of survey team on primate behaviour. Thus, a total of seven field days were realized over the survey period, resulting in a total of $21 \mathrm{~km}$ of transects walked in each stratum for the entire study area.

The starting point of each transect was determined systematically on a gridded map of the study area. The average distance between any two line transects was $3 \mathrm{~km}$. Line transect surveys began early in the morning around 6:30 a.m. and lasted on average for 5-6 hours. Primate calls were used to access the presence and type of primate species in the vicinity of the transects. However, only direct sightings of primates were recorded. All sightings where estimation of group size was difficult to assess were disregarded. When primates were encountered, the number of individuals (group size), species, time, GPS (Garmin GPSmap 62) location, and perpendicular distance to primate(s) were recorded. The distance along transects was measured with a tape measure. The perpendicular ground distance from the transect center line to an estimated central point directly beneath where the primates were initially sighted was also measured using a tape measure. Binoculars were used when necessary to confirm species identity. An index of logging activity per $\mathrm{km}$ was generated by recording the number of logged trees (tree stumps) observed along each transect.

2.3. Data Analysis. Primate density was calculated using DISTANCE Version 4.1 software package [27]. The best model selection was based on the values of Akaike's Information Criterion (AIC) and recommendations by [28]. Encounter rates were calculated in the form of Kilometric Indices of Abundance (KIA), where the number of recorded primates and indicators of logging incidence are presented according to the distance walked during the survey. The Mann-Whitney $U$ test was used to test for any significant difference in primate encounter rates between the logged and unlogged strata. Primate species richness and diversity for each stratum was calculated using EstimateSWin800 Version 8.0.0 software package [29]. Bootstrap Richness Estimator was used for species richness and Shannon-Weiner index for species diversity.

The effect of logging intensity on primate encounter rates was tested using regression analysis in Canoco version 4.5 [30]. Statistical analyses using the program Spatial Analysis in Macroecology [31] were conducted to correct for normality and spatial autocorrelation.

\section{Results}

\subsection{Conservation Status of Primates at Kwabre Forest}

Six Species of Diurnal Primates. Roloway monkey (Cercopithecus roloway), white-naped mangabey (Cercocebus lunulatus), Geoffroy's black-and-white colobus (Colobus vellerosus), olive colobus (Procolobus verus), lesser spot-nosed monkey (Cercopithecus petaurista), and Lowe's monkey (Cercopithecus lowei) were recorded in the survey (Table 1). 


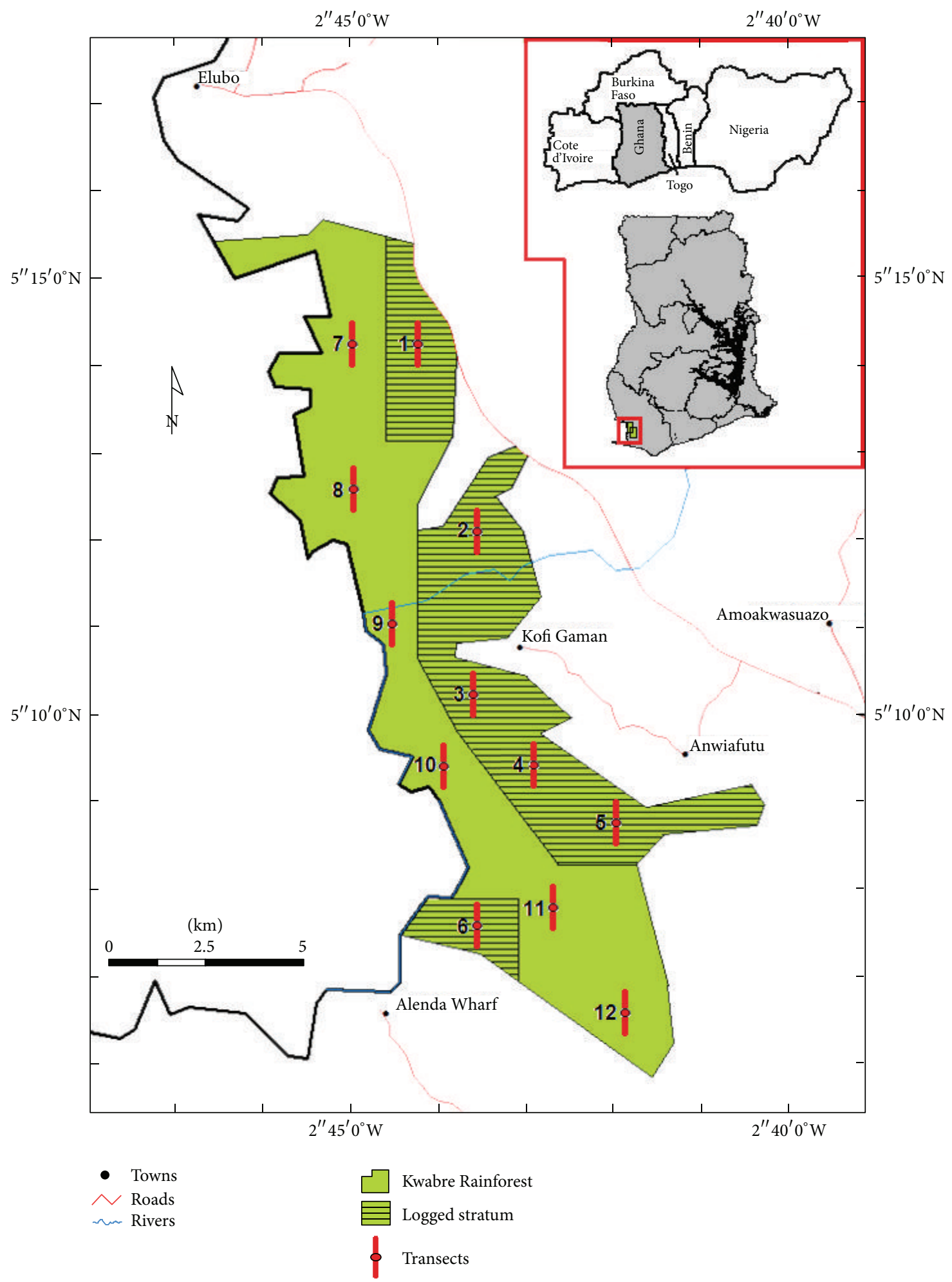

FIGURE 1: Map of Kwabre Rainforest showing the logged stratum.

Roloway monkey is listed as an endangered species on the IUCN Threatened Species List, white-naped mangabey and Geoffroy's black-and-white colobus are listed as vulnerable species, and olive colobus is listed as near-threatened species
[10]. The spot-nosed monkey and Lowe's monkey are considered to be of least concern and are of local conservation importance (Schedule 1) under Ghanaian law (L.I. 1284Wildlife Conservation (Amendment) Regulations, 1983). 


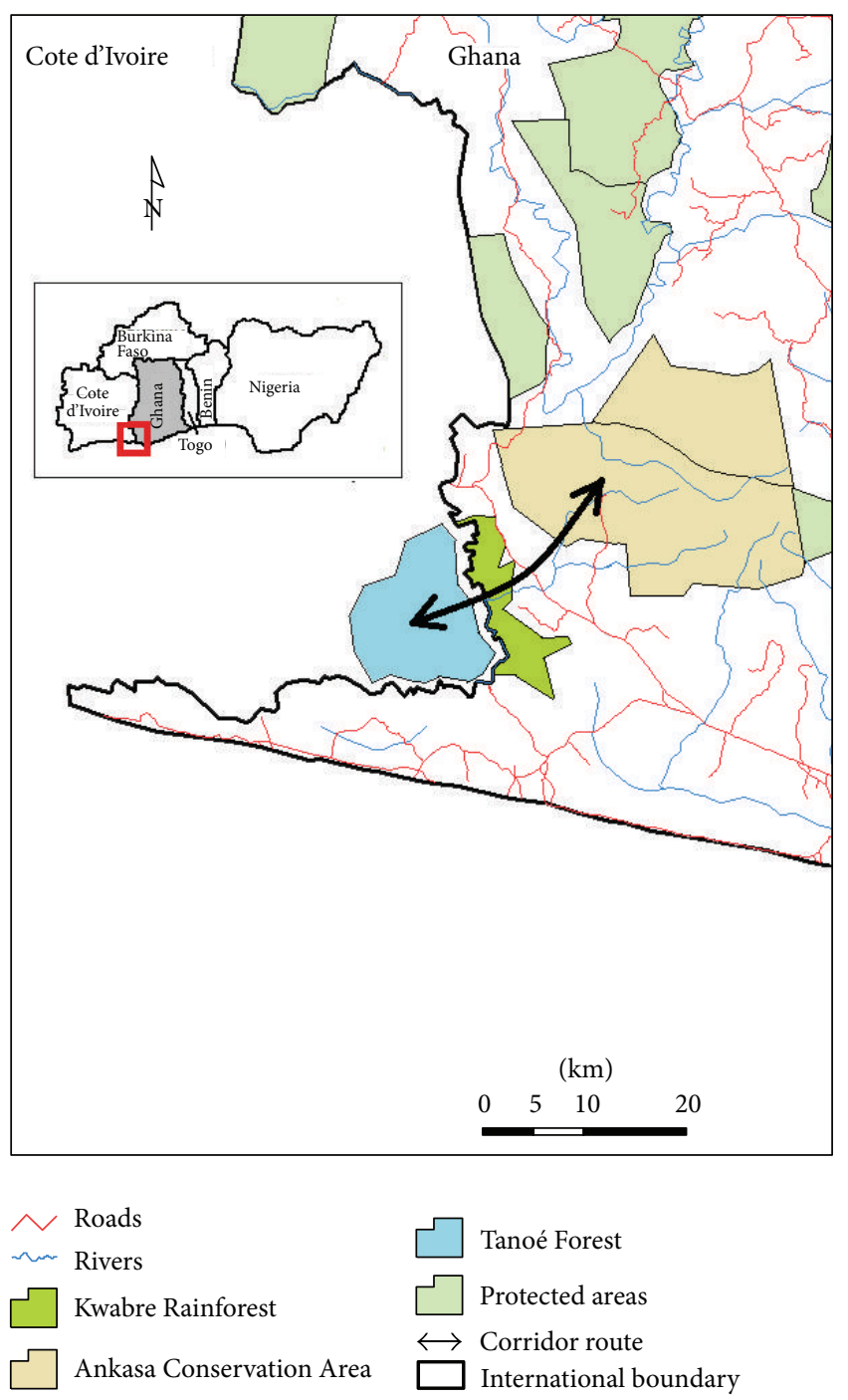

FIGURE 2: Map of the proposed transboundary elephant migration corridor between Ghana and Ivory Coast.

TABLE 1: IUCN status of primate species found in the Kwabre Rainforest.

\begin{tabular}{lcc}
\hline Common name & Scientific name & IUCN status \\
\hline Roloway monkey & Cercopithecus roloway & EN \\
White-naped mangabey & Cercocebus lunulatus & VU \\
Black-and-white colobus & Colobus vellerosus & VU \\
Olive colobus & Procolobus verus & NT \\
Spot-nosed monkey & Cercopithecus petaurista & LC \\
Lowe's monkey & Cercopithecus lowei & LC \\
\hline
\end{tabular}

EN: endangered; VU: vulnerable; NT: near threatened; LC: least concern.

3.2. Primate Diversity. Primate species composition varied across the logged and unlogged strata but was not significantly different (Mann-Whitney $U$ test: $U=36.0, p>0.05$ ). The unlogged stratum was found to be more diverse than logged stratum when various richness and diversity indices
TABle 2: Primate species diversity index generated by EstimateSWin800.

\begin{tabular}{lcc}
\hline Stratum & Shannon-Weiner mean & Standard deviation \\
\hline Logged & 1.44 & 0.22 \\
Unlogged & 2.91 & 0.16 \\
\hline
\end{tabular}

TABLE 3: Pooled primate density parameters estimated for the logged and unlogged strata.

\begin{tabular}{lcc}
\hline Density parameters & $\begin{array}{c}\text { Logged } \\
\text { stratum }\end{array}$ & $\begin{array}{c}\text { Unlogged } \\
\text { stratum }\end{array}$ \\
\hline Density $\left(\mathrm{km}^{-2}\right)$ & 349.93 & 883.68 \\
Percent coefficient of & 22.39 & 10.64 \\
variation $[\mathrm{CV}(\%)]$ & 205.29 & 685.17 \\
Upper confidence limit (CL) & 596.47 & 1139.70 \\
\hline
\end{tabular}

were applied to the data (Table 2). Comparably, these indices were very low in the logged stratum.

None of the species were unique to any of the defined logging categories, but the generally higher primate species richness in the unlogged stratum in comparison to logged stratum may reflect primates' general adaptation to mature forest systems with taller trees and denser canopy covers.

3.3. Primate Density. Primate density was significantly lower (less than 50\%) in the logged stratum compared to the unlogged stratum (Table 3 ). The half normal + cosine model without truncation gave the best fit to the data. Note that DISTANCE produces estimates with asymmetrical confidence limits.

There was also a significant difference in the individual primate encounter rates (Mann-Whitney $U$ test: $U=36.0$, $p<0.01)$ across the two categories of strata, that is, logged and unlogged (Table 4). The percentage of individual primates encountered was considerably greater in the unlogged $(73 \%)$ than in logged $(27 \%)$ stratum; however, primate group sizes for the same species were similar for both strata (Table 4). All species apart from the black-and-white colobus showed greater densities in the unlogged stratum.

3.4. Relationship between Primate Density and Logging Intensity. The number of primates encountered was inversely related to logging intensity $\left(r^{2}=0.945, p<0.01\right)$. The highest encounter rates of primates were observed in slightly logged or unlogged forests (Figure 3).

\section{Discussion}

The results suggest that logging could negatively influence primate communities through the modification of primate density and species composition. Therefore, the null hypothesis of no significant difference in primate density and species composition between logged and unlogged areas is rejected. Such inference must, however, be made cautiously as logging 


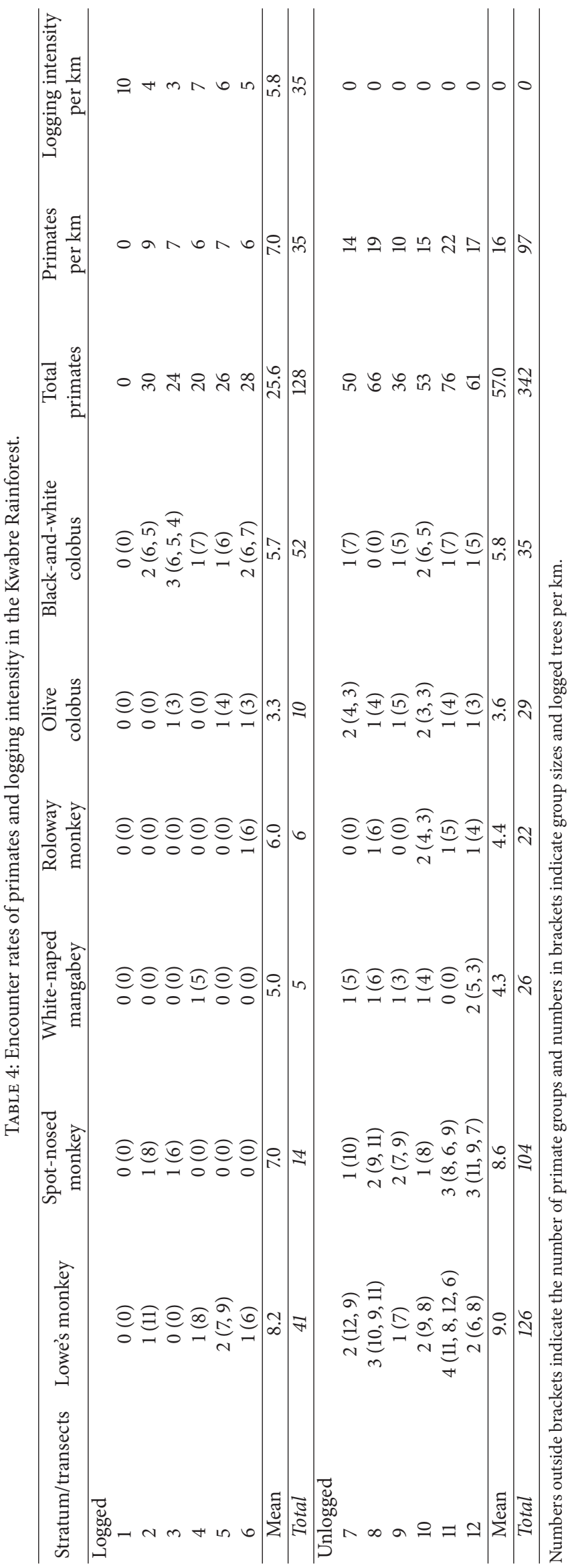




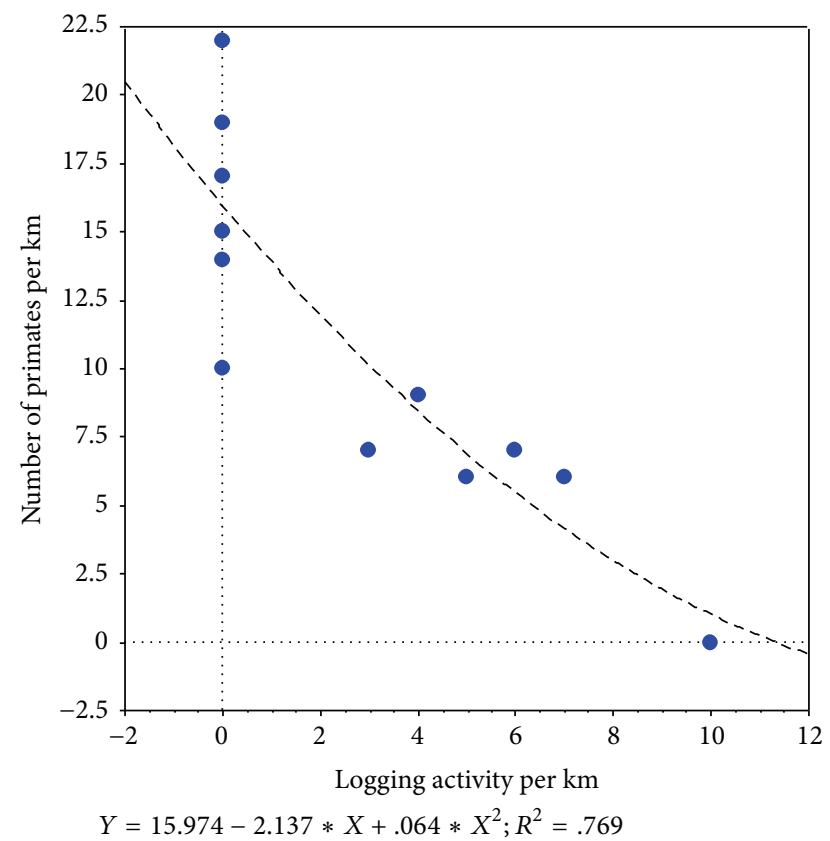

Figure 3: Relationship between encounter rates of primates and logging intensity.

may not be the only factor influencing primate species composition and density. Although both strata possess similar topography and vegetation type, logged areas had recent logging disturbances that resulted in reduced canopy cover and denser understory cover. A factor that may have also influenced our findings could be the proximity of some fringe communities to the forest edge. During the study, it was observed that logged areas were closer to fringe communities and farms, making such areas more susceptible to human disturbances such as poaching $[17,32]$. Some of these differences in human and ecological variables may have influenced our findings. One reason that may have accounted for higher numbers of black-and-white colobuses in the logged stratum is that they are folivores [14] and as such may show preference for degraded areas where the open canopy permits growth of diverse understory. Apart from changes in density and diversity, logging might have also affected the behaviour of primates $[13,20,33]$. For instance, primates exhibited extreme shyness including restricting calls in the logged stratum compared to the unlogged stratum when teams encountered primate groups. The apparent differences in the incidence of alarm calls between groups of monkeys encountered between the two strata could affect our census findings to a small extent. However, previous studies on primate surveys [14, 24, 34] have shown that many replications are needed at each transect before the group density estimates can be considered reliable. In the current study, each transect was sampled more than once and this could increase the reliability of our results.

Our study draws attention to matters of both national and international conservation concern. The evidence of unauthorized human activities recorded during this study indicates clearly that the community-based management system practiced at Kwabre Rainforest may not be effective in preventing poaching and other illegal human activities in the forest. If current threats continue unabated, then rapid population decline of primates is expected in the near future.

Given its considerably intact forest cover, Ghana is in a position to implement important forest conservation initiatives in the subregion $[35,36]$. Within Ghana, the general vicinity of the Kwabre Rainforest is very significant from a regional viewpoint because it constitutes part of a network of forest reserves in southwestern Ghana which constitutes Ghana's portion of the proposed crucial corridor for wildlife between the Ankasa Conservation Area in Ghana and the Tanoé Forest in Cote d'Ivoire [9].

In this regional setting, the future management of the Kwabre corridor could be very important. At present, farms and villages are flourishing along the Kwabre corridor, rapidly increasing local human pressure. Concerns about the future of Kwabre corridor are particularly important because interest to protect wildlife in the area has waned and Kwabre Rainforest could face a sudden increase in hunting, logging, and slash-and-burn farming. Instead of acting as a community forest buffer zone and possible faunal corridor between two key international protected areas (Ankasa Conservation Area in Ghana and Tanoé Forest in neighbouring Cote d'Ivoire, Figure 2), the larger Kwabre corridor area could instead become a major population sink for wildlife $[13,37,38]$. This would reinforce adverse edge effects and genetic isolation of the protected areas, increasing the probability of local extinctions of species of conservation interest $[39,40]$.

\section{Conclusions and Recommendations}

Kwabre Rainforest is an important site where careful wildlife management can support major biodiversity conservation in Ghana; hence, more effort should be channeled into preventing further habitat degradation of the larger Kwabre Rainforest corridor area. One possibility would be to grant the Kwabre Rainforest protected area status under Ghanaian law and to manage it under the umbrella of an integrated conservation plan that includes its two adjacent international protected areas. Such a plan can be achieved by designating the entire area as a biosphere reserve, which would permit planned development outside reserves while affording high protection for protected areas [41]. With effective longterm management, this region of southwestern Ghana could remain one of the most important areas for wildlife in West Africa.

\section{Competing Interests}

The authors declare that there are no competing interests regarding the publication of this paper.

\section{Acknowledgments}

Many thanks are due to the traditional head and people of Kwabre. 


\section{References}

[1] B. Czech, P. R. Krausman, and P. K. Devers, "Economic associations among causes of species endangerment in the United States," BioScience, vol. 50, no. 7, pp. 593-601, 2000.

[2] D. S. Wilcove, C. H. Mclellan, and A. P. Dobson, "Habitat fragmentation in the temperate zone," in Conservation Biology: The Science of Scarcity and Species Richness, M. E. Soule, Ed., pp. 237-256, Sinauer Associates, Sunderland, Mass, USA, 1998.

[3] A. G. Chiarello, "Density and population size of mammals in remnants of Brazilian Atlantic forest," Conservation Biology, vol. 14, no. 6, pp. 1649-1657, 2000.

[4] R. K. Laidlaw, "Effects of habitat disturbance and protected areas on mammals of Peninsular Malaysia," Conservation Biology, vol. 14, no. 6, pp. 1639-1648, 2000.

[5] M. A. Lopes and S. F. Ferrari, "Effects of human colonization on the abundance and diversity of mammals in eastern Brazilian Amazonia," Conservation Biology, vol. 14, no. 6, pp. 1658-1665, 2000.

[6] E. Carrillo, G. Wong, and N. A. D. Cuarón, "Monitoring mammal populations in Costa Rican protected areas under different hunting restrictions," Conservation Biology, vol. 14, no. 6, pp. 1580-1591, 2000.

[7] M. Conroy and D. Nichols, "Designing a study to assess mammalian diversity," in Measuring and Monitoring Biological Diversity. Standard Methods for Mammals, D. Wilson, R. Cole, J. Nichols, R. Rudran, and M. Foster, Eds., pp. 41-49, Smithsonian Institution Press, London, UK, 1996.

[8] WAPCA, Annual Report. West African Primate Conservation Action, WAPCA, Accra, Ghana, 2012.

[9] D. Osei, R. H. Horwich, and J. M. Pittman, "First sightings of the Roloway Monkey (Cercopithecus diana roloway) in Ghana in ten years and the status of other endangered primates in Southwestern Ghana," African Primates, vol. 10, pp. 25-40, 2015.

[10] The IUCN Red List of Threatened Species, Version 2015.2, 2015, http://www.iucnredlist.org/.

[11] W. S. McGraw and J. F. Oates, "Roloway monkey Cercopithecus diana roloway (Schreber, 1774)," in Primates in Peril: The World's Most Endangered Primates 2012-2014, C. Schwitzer, R. A. Mittermeier, A. B. Rylands et al., Eds., pp. 14-16, IUCN SSC Primate Specialist Group (PSG), International Primatological Society (IPS), Conservation International (CI), and Bristol Zoological Society, Arlington, Va, USA, 2014.

[12] R. A. Mittermeier, J. Ratsimbazafy, A. B. Rylands et al., "Primates in peril: the world's 25 most endangered primates, 20062008," Primate Conservation, vol. 22, pp. 1-40, 2007.

[13] D. Swift, "The consequences of logging on primate density and diversity in Kibale National Park, Uganda," Bioscience Horizons, vol. 5, pp. 1-6, 2012.

[14] C. A. Chapman, L. J. Chapman, L. Naughton-Treves, M. J. Lawes, and L. R. Mcdowell, "Predicting folivorous primate abundance: validation of a nutritional model," American Journal of Primatology, vol. 62, no. 2, pp. 55-69, 2004.

[15] J. P. Skorupa, The effects of selective timber harvesting on rain-forest primates in Kibale Forest, Uganda [Ph.D. thesis], University of California, Davis, Davis, Calif, USA, 1988.

[16] T. T. Struhsaker, Ecology of an African Rainforest: Logging in Kibale and the Conflict between Conservation and Exploitation, University Press of Florida, Gainesville, Fla, USA, 1997.

[17] P. Mayor, P. Pérez-Peña, M. Bowler, P. E. Puertas, M. Kirkland, and R. Bodmer, "Effects of selective logging on large mammal populations in a remote indigenous territory in the northern peruvian amazon," Ecology and Society, vol. 20, no. 4, pp. 3644, 2015.

[18] A. J. Plumptre and V. Reynolds, "The effect of selective logging on the primate populations in the Budongo Forest Reserve, Uganda," Journal of Applied Ecology, vol. 31, no. 4, pp. 631-641, 1994.

[19] C. Mammides, M. Cords, and M. K. Peters, "Effects of habitat disturbance and food supply on population densities of three primate species in the Kakamega Forest, Kenya," African Journal of Ecology, vol. 47, no. 1, pp. 87-96, 2009.

[20] C. Schwitzer, L. Glatt, K. A.-I. Nekaris, and J. U. Ganzhorn, "Responses of animals to habitat alteration: an overview focussing on primates," Endangered Species Research, vol. 14, no. 1, pp. 31-38, 2011.

[21] R. Rimbach, A. Link, M. Heistermann, C. Gómez-Posada, N. Galvis, and E. W. Heymann, "Effects of logging, hunting, and forest fragment size on physiological stress levels of two sympatric ateline primates in Colombia," Conservation Physiology, vol. 1, no. 1, Article ID cot031, pp. 1-11, 2013.

[22] R. F. W. Barnes, K. L. Barnes, M. P. T. Alers, and A. Blom, "Man determines the distribution of elephants in the rain forests of northeastern Gabon," African Journal of Ecology, vol. 29, no. 1, pp. 54-63, 1991.

[23] R. F. W. Barnes, K. Beardsley, F. Michelmore, K. L. Barnes, M. P. T. Alers, and A. Blom, "Estimating forest elephant numbers with dung counts and a geographic information system," Journal of Wildlife Management, vol. 61, no. 4, pp. 1384-1393, 1997.

[24] S. A. Lahm, R. F. W. Barnes, K. Beardsley, and P. Cervinka, "A method for censusing the greater white-nosed monkey in northeastern Gabon using the population density gradient in relation to roads," Journal of Tropical Ecology, vol. 14, no. 5, pp. 629-643, 1998.

[25] L. Sebogo and R. F. W. Barnes, "Action plan for the management of trans-frontier elephant conservation corridors in West Africa," Tech. Rep., IUCN/AfESG, Ouagadougou, Burkina Faso, 2003.

[26] J. F. Oates, M. Abedi-Lartey, W. S. McGraw, T. T. Struhsaker, and G. H. Whitesides, "Extinction of a West African red colobus monkey," Conservation Biology, vol. 14, no. 5, pp. 1526-1532, 2000.

[27] L. Thomas, J. L. Laake, S. Strindberg et al., Distance 4.0, Release 1. Research Unit for Wildlife Population Assessment, University of St Andrews, St Andrews, Scotland, 2002.

[28] S. T. Buckland, D. R. Anderson, K. P. Burnham, J. L. Laake, D. L. Borchers, and L. Thomas, Introduction to Distance Sampling: Estimating Abundance of Biological Populations, Oxford University Press, Oxford, UK, 2001.

[29] R. K. Colewell, EstimateS: Statistical Estimation of Species Richness and Shared Species from Samples, Version 8, 2006, http://purl.oclc.org/estimates.

[30] C. J. F. Ter Braak and P. Imilauer, Canoco Reference Manual and CanoDraw for Windows User's Guide: Software for Canonical Community Ordination (Version 4.5), Microcomputer Power, Ithaca, NY, USA, 2002.

[31] T. F. L. V. B. Rangel, J. A. F. Diniz-Filho, and L. M. Bini, “Towards an integrated computational tool for spatial analysis in macroecology and biogeography," Global Ecology and Biogeography, vol. 15, no. 4, pp. 321-327, 2006.

[32] W. F. Laurance, B. M. Croes, L. Tchignoumba et al., "Impacts of roads and hunting on central African rainforest mammals," Conservation Biology, vol. 20, no. 4, pp. 1251-1261, 2006. 
[33] C. A. Chapman, S. R. Balcomb, T. R. Gillespie, J. P. Skorupa, and T. T. Struhsaker, "Long-term effects of logging on African primate communities: a 28-year comparison from Kibale National Park, Uganda," Conservation Biology, vol. 14, no. 1, pp. 207-217, 2000.

[34] S. A. Lahm and J. P. Tezi, "Assessment of the communities of medium-sized and large arboreal and terrestrial mammals in the Rabi-Toucan region of the Ngove-Ndogo Hunting Domain and southwestern Loango National Park," Bulletin of the Biological Society of Washington, vol. 12, pp. 383-416, 2006.

[35] W. F. Laurance, A. Alonso, M. Lee, and P. Campbell, "Challenges for forest conservation in Gabon, Central Africa," Futures, vol. 38, no. 4, pp. 454-470, 2006.

[36] A. Kamdem-Toham, A. W. Adeleke, N. D. Burgess et al., "Forest conservation in the Congo Basin," Science, vol. 299, no. 5605, article 346, 2003.

[37] A. J. Novaro, K. H. Redford, and R. E. Bodmer, "Effect of hunting in source-sink systems in the Neotropics," Conservation Biology, vol. 14, no. 3, pp. 713-721, 2000.

[38] C. A. Peres, "Synergistic effects of subsistence hunting and habitat fragmentation on amazonian forest vertebrates," Conservation Biology, vol. 15, no. 6, pp. 1490-1505, 2001.

[39] R. Woodroffe and J. R. Ginsberg, "Edge effects and the extinction of populations inside protected areas," Science, vol. 280, no. 5372, pp. 2126-2128, 1998.

[40] W. F. Laurance, T. E. Lovejoy, H. L. Vasconcelos et al., "Ecosystem decay of Amazonian forest fragments: a 22-year investigation," Conservation Biology, vol. 16, no. 3, pp. 605-618, 2002.

[41] A. Kaus, "Environmental perceptions and social relations in the Mapimí Biosphere Reserve," Conservation Biology, vol. 7, no. 2, pp. 398-406, 1993. 

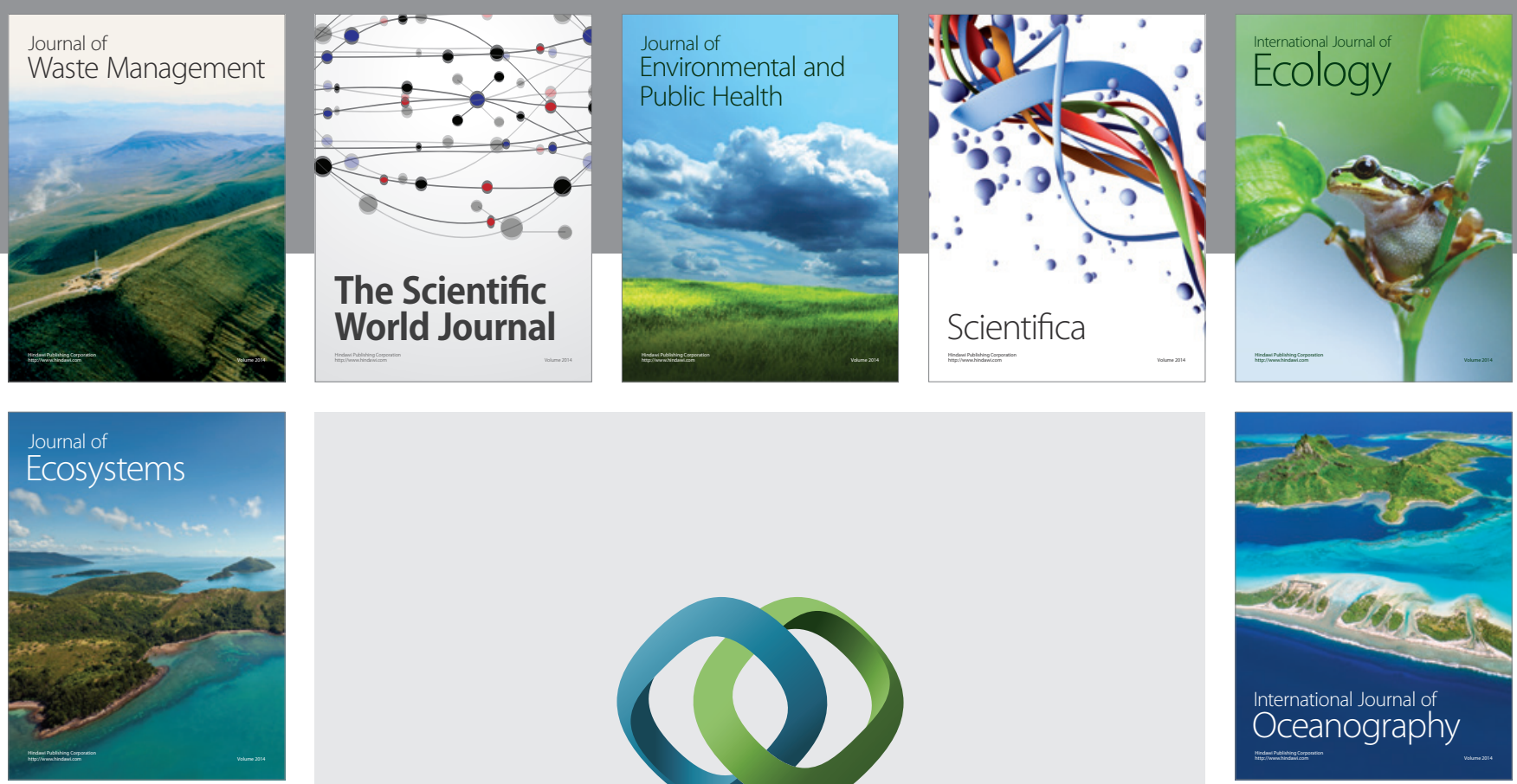

The Scientific World Journal
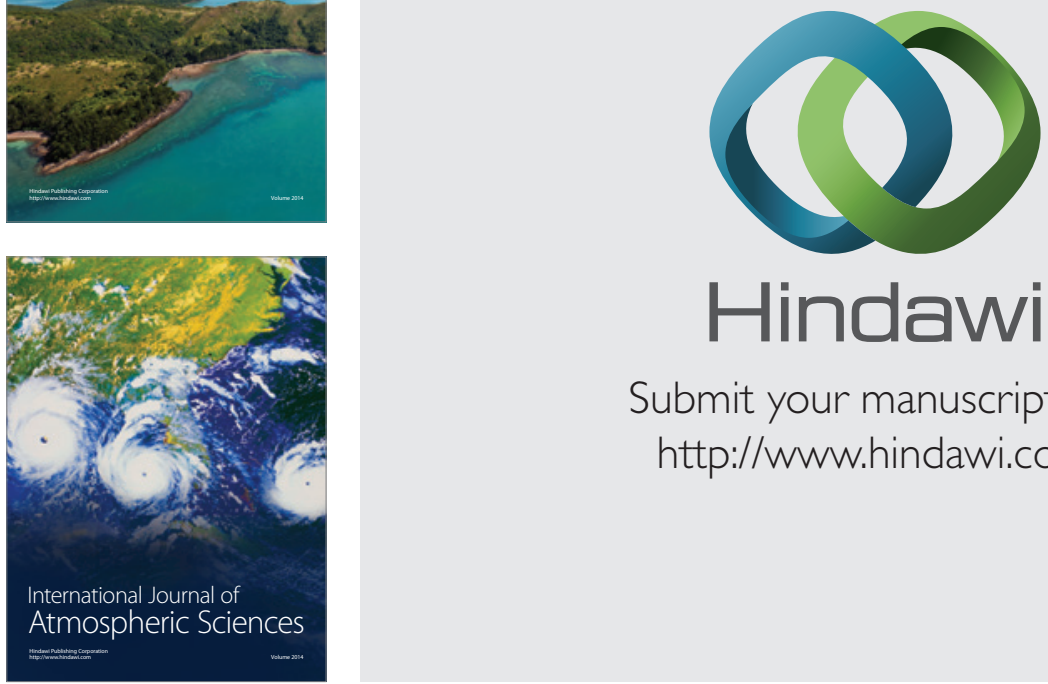

\section{Hindawi}

Submit your manuscripts at

http://www.hindawi.com
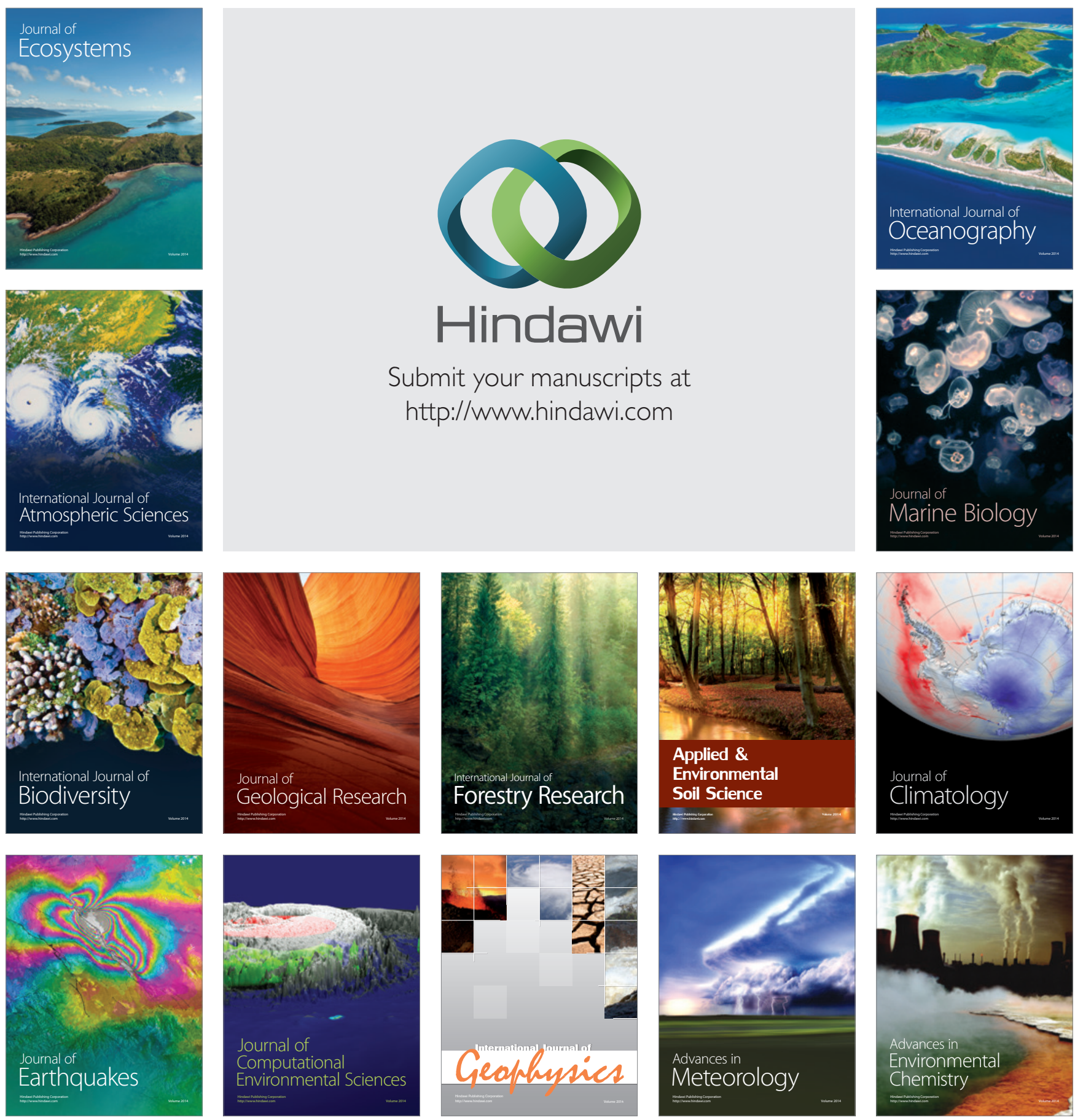